\title{
Cortical Glutamatergic Markers in Schizophrenia
}

\author{
Elizabeth Scarr*,1,2, Monica Beneyto ${ }^{3}$, James H Meador-Woodruff ${ }^{3}$ and Brian Dean ${ }^{1,4,5,6}$ \\ 'Rebecca L Cooper Research Laboratories, The Mental Health Research Institute of Victoria, Parkville, Australia; ${ }^{2}$ Centre for Neuroscience, The \\ University of Melbourne, Parkville, Australia; ${ }^{3}$ Department of Psychiatry, Mental Health Research Institute, University of Michigan, Ann Arbor, Ml, \\ USA; ${ }^{4}$ Department of Pathology, The University of Melbourne, Parkville, Australia; ${ }^{5}$ Department of Psychiatry, The University of Melbourne, \\ Parkville, Australia; ${ }^{6}$ Department of Psychological Medicine, Monash University, Clayton, Australia
}

\begin{abstract}
Post-mortem studies have yet to produce consistent findings on cortical glutamatergic markers in schizophrenia; therefore, it is not possible to fully understand the role of abnormal glutamatergic function in the pathology of the disorder. To better understand the changes in cortical glutamatergic markers in schizophrenia, we measured the binding of radioligands to the ionotropic glutamate receptors (N-methyl D-aspartate, $\left.{ }^{3} \mathrm{H}\right]$ CGP39653, $\left.\left[{ }^{3} \mathrm{H}\right] \mathrm{MK}-80 \mathrm{I}\right)$, amino-3-hydroxy-5-methyl-4-isoxazole ([ $\left.\left.{ }^{3} \mathrm{H}\right] \mathrm{AMPA}\right)$, kainate $\left(\left[{ }^{3} \mathrm{H}\right]\right.$ kainate), and the high-affinity glutamate uptake site $\left(\left[{ }^{3} \mathrm{H}\right]\right.$ aspartate $)$ using in situ radioligand binding with autoradiography and levels of mRNA for kainate receptors using in situ hybridization in the dorsolateral prefrontal cortex from 20 subjects with schizophrenia and 20 controls matched for age and sex. Levels of $\left[{ }^{3} \mathrm{H}\right]$ kainate binding were significantly decreased in cortical laminae I-II $(p=0.0 \mathrm{I})$, III-IV $(p<0.05)$, and $\mathrm{V}-\mathrm{VI}(p<0.0 \mathrm{I})$ from subjects with schizophrenia. By contrast, levels of $\left[{ }^{3} \mathrm{H}\right] \mathrm{MK}-80 \mathrm{I},\left[{ }^{3} \mathrm{H}\right] \mathrm{AMPA},\left[{ }^{3} \mathrm{H}\right] \mathrm{aspartate}, \mathrm{or}$ $\left.{ }^{3} \mathrm{H}\right]$ CGP39653 binding did not differ between the diagnostic cohorts. Levels of mRNA for the GluR5 subunit were decreased overall $(p<0.05)$, with no changes in levels of mRNA for GluR6, GluR7, KAI, or KA2 in tissue from subjects with schizophrenia. These data indicate that the decreased number of kainate receptors in the dorsolateral prefrontal cortex in schizophrenia may result, in part, from reduced expression of the GluR5 receptor subunits.

Neuropsychopharmacology (2005) 30, I52 I-I53I advance online publication, I I May 2005; doi: I 0. I038/sj.npp. I 300758
\end{abstract}

Keywords: receptors; glutamate; mental disorders; human; in situ hybridization; autoradiography

\section{INTRODUCTION}

Glutamate, the most abundant and best characterized of the excitatory amino acids in the central nervous system (CNS), is thought to influence the activity of most neurons (Fagg and Foster, 1983). Glutamate acts through a number of receptors that affect both fast and slow neurotransmission and are accordingly divided into ionotropic and G-proteincoupled metabotropic receptors (Hollmann and Heinemann, 1994). The family of pharmacologically distinct ionotropic receptors is made up of the $N$-methyl-D-aspartate (NMDA) receptor, the amino-3-hydroxy-5-methyl-4-isoxazole (AMPA) receptor, and the kainate receptor. Each ionotropic receptor is a multimeric aggregation of different protein subunits that combine to form a ligand-gated ion channel. For the NMDA receptor, NMDAR1 is the obligate subunit and combines with NMDAR2A-2D subunits to

\footnotetext{
* Correspondence: Dr E Scarr, Rebecca L Cooper Research Laboratories, The Mental Health Research Institute of Victoria, Locked Bag I I, Parkville, VIC 3052, Australia, E-mail: escarr_mhri@iprimus.com.au Received 18 January 2005; revised 23 March 2005; accepted 24 March 2005

Online publication: I April 2005 at http://www.acnp.org/citations/ Npp040 105050037/default.pdf
}

form a gated channel. AMPA receptors are formed from four different subunits, termed GluR1-4, all of which can exist in two different forms, while the five different kainate subunits (GluR5-7 and KA1-2) can undergo alternative splicing and editing (Nakanishi, 1992).

The cornerstone of the glutamatergic hypothesis of schizophrenia is the observation that phencyclidine (PCP, angel dust) can induce psychoses similar to that associated with schizophrenia (Luisada, 1978) and binds to the NMDA receptor (Loo et al, 1987). Adding weight to the argument that the NMDA receptor is involved in the pathology of schizophrenia is the neuropsychopharmacological observation that ketamine, which is a noncompetitive NMDA antagonist (White et al, 1982), increases the severity of the positive symptoms of schizophrenia (Lahti et al, 1995). In addition, after receiving ketamine, some of the schizophrenic subjects who received the drug reported that 'they felt as if they had stopped their antipsychotic medication' (Tamminga, 1999). Thus, data from neuropsychopharmacological studies have focused attention on the NMDA receptor and its possible role in the pathology of schizophrenia.

Studies using post-mortem CNS from subjects with schizophrenia have attempted to understand changes in the NMDA receptor in schizophrenia, but have not yet fully 
defined the mechanisms by which changes in the NMDA receptor could induce symptoms associated with the disorder. However, such studies have revealed regionspecific changes in NMDA and other ionotropic glutamate receptors at the level of protein and mRNA in brain tissue from subjects with the disorder. In a recent review of the available post-mortem data (Meador-Woodruff and Healy, 2000), it was highlighted that there are some consistencies regarding glutamate receptors in schizophrenia. These include decreased expression of the NMDAR1 subunit for the NMDA receptor in some cortical areas, decreases in both kainate and AMPA receptors in the hippocampal formation, and a decrease in kainate but not AMPA receptors in the cortex from subjects with the disorder. Overall, this review supported the hypothesis that abnormalities in cortical glutamatergic ionotropic receptors are a critical component of the changes in the glutamatergic system in subjects with schizophrenia.

Of particular relevance to the glutamatergic hypothesis of schizophrenia are recent reviews of genetic studies (Harrison and Weinberger, 2005; Owen et al, 2005), which highlight associations between the expression of polymorphisms in genes for proteins associated with synapses, particularly glutamatergic synapses, with increased susceptibility to schizophrenia. Three such proteins are (i) dysbindin 1 , overexpression of which has been shown to increase glutamate release by neuronal cultures (Numakawa et al, 2004); (ii) neuregulin 1, heterozygote knockouts of which have lower NMDA receptors and showed abnormal prepulse inhibition (an animal model used to predict antipsychotic activity in compound development) and hyperactivity in novel environments (Stefansson et al, 2002); and (iii) G72, a protein that activates D-amino-acid oxidase (DAAO), one of the enzymes involved in metabolizing D-serine, known to be an agonist at one of the NMDA receptor modulatory sites (Chumakov et al, 2002). The convergence of the products of these three susceptibility genes on the glutamatergic system augments the neuropsychological and post-mortem work emphasizing a role for the system in the pathology of schizophrenia.

A growing body of data supports the position that the functioning of the glutamatergic system relies on a high degree of interactivity between ionotropic glutamate receptors. For example, presynaptic kainate (Perkinton and Sihra, 1999) and NMDA (Breukel et al, 1998) receptors modulate glutamate release, while both kainate and AMPA receptors act to depolarize the postsynaptic membrane, reducing the ion channel block at the NMDA receptor (Goff and Coyle, 2001). These data suggest that a comprehensive study of ionotropic glutamate receptors within the same cohorts of subjects is most likely to provide insight into how changes in these receptors might precipitate the onset of the symptoms of schizophrenia. Thus, to gain a more global view of changes in cortical ionotropic glutamate receptors in schizophrenia, we have measured the densities of NMDA ([ $\left.{ }^{3} \mathrm{H}\right] \mathrm{MK}-801$ binding (open ion channels) and $\left[{ }^{3} \mathrm{H}\right]_{\mathrm{D}, \mathrm{L}}$-(E)-2-amino-4-propyl-5-phosphono-3-pentanoic acid ( $\left[{ }^{3} \mathrm{H}\right]$ CGP39653) binding (glutamate binding site)), AMPA ([ $\left.{ }^{3} \mathrm{H}\right]$ AMPA binding), and kainate $\left(\left[{ }^{3} \mathrm{H}\right]\right.$ kainate binding) receptors, as well as that of the high-affinity glutamate transporter $\left(\left[{ }^{3} \mathrm{H}\right]\right.$ aspartate) in Brodmann's area (BA) 9 obtained from subjects with the disorder and subjects with no history of psychiatric illness (controls). In order to determine whether the changes we saw in radioligand binding were associated with changes in transcript expression, we have also measured levels of mRNA for all of the kainate receptor subunits using in situ hybridization.

\section{MATERIALS AND METHODS}

$\left[{ }^{3} \mathrm{H}\right] \mathrm{CGP} 39653,\left[{ }^{3} \mathrm{H}\right] \mathrm{MK}-801,\left[{ }^{3} \mathrm{H}\right] \mathrm{AMPA},\left[{ }^{3} \mathrm{H}\right]$ kainate, and $\left[{ }^{3} \mathrm{H}\right]$ aspartate were obtained from New England Nuclear. L-Glutamic acid, quisqualic acid, spermidine, and potassium thiocyanate were obtained from Sigma-Aldrich Pty. Ltd, as were all other laboratory-grade reagents. Kodak BIOMAX MR film and D19 developer were obtained from Kodak, Rochester, NY. Hyperfilm $\left[{ }^{3} \mathrm{H}\right],\left[{ }^{3} \mathrm{H}\right]$ microscales ${ }^{\mathrm{TM}}$, and $\left[{ }^{14} \mathrm{C}\right]$ microscales ${ }^{\mathrm{TM}}$ were obtained from Amersham Biosciences Pty., Ltd.

\section{Tissue Preparation}

Consent for the study was obtained from the Ethics Committee of the Victorian Institute of Forensic Medicine and the North Western Mental Health Program Behavioural and Psychiatric Research and Ethics Committee. Postmortem tissue used in this study was obtained at autopsy and held in the CNS repository at the Rebecca L Cooper Research Laboratories. Blocks of tissue, containing BA 9, were removed from the left cerebral cortex of 20 subjects with a preliminary diagnosis of schizophrenia and 20 subjects, matched for age and sex, with no history of psychiatric illness (controls). The diagnosis of schizophrenia was confirmed from case histories, according to DSMIV criteria (American Psychiatric Association, 1994), by a senior psychologist and a psychiatrist using the Diagnostic Instrument for Brain Studies (Hill et al, 1999). The duration of illness (DOI - the interval between the first hospital admission and time of death) and the last recorded antipsychotic drug doses, expressed as chlorpromazine equivalents (Remington, 1999), were calculated (Table 1). The $\mathrm{pH}$ of the tissue was measured to assess the agonal status of the brain (Kingsbury et al, 1995). Where the death was witnessed, the post-mortem interval (PMI) was the time between death and autopsy. In cases where the death was not witnessed, the PMI was taken as being half of the interval between the individual last being seen alive and being found dead. Cases were accepted when less than $5 \mathrm{~h}$ elapsed between the subject last being seen alive and being found dead. All samples were stored frozen at $-70^{\circ} \mathrm{C}$ from the time of autopsy.

\section{In Situ Radioligand Binding}

A total of 20 sections $(20 \mu \mathrm{m})$ were cut from the BA 9 blocks taken from the lateral surface of the frontal lobe, within the region bordered by the middle frontal gyrus superior and the inferior frontal sulcus. The sections were thaw mounted on gelatinized slides.

The binding densities of the radioligands $\left[{ }^{3} \mathrm{H}\right] \mathrm{MK}-801$, $\left[{ }^{3} \mathrm{H}\right] \mathrm{CGP} 39653,\left[{ }^{3} \mathrm{H}\right]$ AMPA, $\left[{ }^{3} \mathrm{H}\right]$ kainate, and $\left[{ }^{3} \mathrm{H}\right] \mathrm{D}$-aspartate were essentially determined as previously described. Thus, for the determination of $\left[{ }^{3} \mathrm{H}\right] \mathrm{MK}-801$ binding, sections were preincubated in assay buffer $(50 \mathrm{mM}$ 
Table I Demographics of Subjects from whom Tissue was Used for the Study of Cortical Glutamate

\begin{tabular}{|c|c|c|c|c|c|c|}
\hline Schizoph & Age & Sex & PMI & Brain pH & Antipsychotic (mg, schedule) & Chlor. Eq. \\
\hline । & 67.0 & M & 21.0 & 6.46 & Fluphenazine (37.5, fortnight) & 75.0 \\
\hline 2 & 22.0 & M & 37.0 & 6.07 & Trifluoperazine (15); flupenthixol (40, 4 weeks) & 450.0 \\
\hline 3 & 40.0 & $\mathrm{~F}$ & 61.0 & 5.71 & Fluphenazine (25, fortnight; 5) & 550.0 \\
\hline 4 & 53.0 & M & 37.0 & 5.98 & Fluphenazine (75, fortnight); Chlorpromazine (800) & 1700.0 \\
\hline 5 & 81.0 & $\mathrm{~F}$ & 25.0 & 6.31 & Trifluoperazine (5) & 100.0 \\
\hline 8 & 32.0 & M & 17.0 & 6.05 & Haloperidol (200, 4 weeks) & 670.0 \\
\hline 9 & 46.0 & M & 42.0 & 5.53 & Haloperidol (50, 4 weeks) & 160.0 \\
\hline 10 & 22.0 & $M$ & 37.0 & 6.17 & Pimozide (4) & 200.0 \\
\hline 11 & 68.0 & $\mathrm{~F}$ & 42.0 & 5.73 & Trifluoperazine (20) & 400.0 \\
\hline 16 & 35.0 & $\mathrm{~F}$ & 39.0 & 6.38 & Resperidone (3) & 150.0 \\
\hline 17 & 69.0 & M & 44.5 & 6.38 & Trifluoperazine (5) & 100.0 \\
\hline 18 & 42.0 & M & 47.0 & 6.26 & Fluphenazine (75, fortnight) & 1000.0 \\
\hline 19 & 47.0 & M & 41.5 & 6.52 & Chlorpromazine (400); haloperidol (I50, fortnight) & 1400.0 \\
\hline 20 & 61.0 & M & 37.5 & 6.46 & Fluphenazine (62.5, fortnight) & 745.5 \\
\hline Mean \pm SEM & $49.35 \pm 3.8$ & & $41.20 \pm 2.8$ & $6.16 \pm 0.06$ & & $473.0 \pm 100.7$ \\
\hline Controls & Age & Sex & PMI & Brain pH & & \\
\hline । & 65.0 & M & 20.5 & 6.47 & & \\
\hline 8 & 35.0 & M & 55.0 & 6.52 & & \\
\hline 9 & 46.0 & M & 46.5 & 6.08 & & \\
\hline 10 & 22.0 & M & 62.0 & 6.39 & & \\
\hline 11 & 66.0 & $\mathrm{~F}$ & 43.0 & 6.37 & & \\
\hline 12 & 43.0 & M & 45.0 & 6.25 & & \\
\hline 13 & 42.0 & $M$ & 63.0 & 6.34 & & \\
\hline 14 & 48.0 & $M$ & 52.0 & 5.99 & & \\
\hline 15 & 72.0 & $M$ & 39.0 & 6.21 & & \\
\hline 16 & 33.0 & $\mathrm{~F}$ & 42.0 & 6.41 & & \\
\hline 17 & 68.0 & $M$ & 41.0 & 6.06 & & \\
\hline 18 & 38.0 & $M$ & 46.0 & 6.42 & & \\
\hline 19 & 42.0 & $M$ & 43.0 & 6.61 & & \\
\hline 20 & 67.0 & M & 32.0 & 6.14 & & \\
\hline Mean \pm SEM & $49.00 \pm 3.8$ & & $45.0 \pm 2.4$ & $6.34 \pm 0.04$ & & \\
\hline
\end{tabular}

Schizoph = schizophrenics, age is given in years, PMI = post-mortem interval (h), Chlor. Eq. = chlorpromazine equivalents (mg).

Tris-acetate ( $\mathrm{pH} 7.4)$ containing $100 \mu \mathrm{M}$ glutamate, $50 \mu \mathrm{M}$ glycine, and $50 \mu \mathrm{M}$ spermidine) at room temperature (RT) for $30 \mathrm{~min}$. The specific binding of $\left[{ }^{3} \mathrm{H}\right] \mathrm{MK}-801(20 \mathrm{nM})$ was defined as the difference in radiolabel binding in the absence (TB) and presence (NS) of MK-801 (100 $\mu \mathrm{M})$ following a $60 \mathrm{~min}$ incubation, in assay buffer, at RT 
(Johnson et al, 1993). [ $\left.{ }^{3} \mathrm{H}\right] \mathrm{CGP} 39653$ binding density was determined following a $45 \mathrm{~min}$ preincubation in assay buffer (50 mM Tris-HCl, $\mathrm{pH} \mathrm{8)}$ at RT. Sections were incubated in assay buffer with $\left[{ }^{3} \mathrm{H}\right] \mathrm{CGP} 39653(20 \mathrm{nM})$ in the absence (TB) or presence (NS) of L-glutamic acid ( $1 \mathrm{mM}$ ) for $45 \mathrm{~min}$ at RT (Ibrahim et al, 2000a). Determination of $\left[{ }^{3} \mathrm{H}\right] \mathrm{AMPA}$ binding followed a $30 \mathrm{~min}$ preincubation in assay buffer (50 mM Tris- $\mathrm{HCl}$ ( $\mathrm{pH} 7.4$ ) containing $2.5 \mathrm{mM} \mathrm{CaCl}_{2}$ and $0.1 \mathrm{M}$ potassium thiocyanate) at $\mathrm{RT}$. Nonspecific sections were incubated with $\left[{ }^{3} \mathrm{H}\right]$ AMPA $(100 \mathrm{nM})$ in the presence of $100 \mu \mathrm{M}$ quisqualic acid, while those for total binding were incubated with $\left[{ }^{3} \mathrm{H}\right]$ AMPA $(100 \mathrm{nM})$ only in assay buffer for $45 \mathrm{~min}$ at $4^{\circ} \mathrm{C}$ (Jansen et al, 1990). Sections for the determination of $\left[{ }^{3} \mathrm{H}\right]$ kainate were first preincubated in assay buffer ( $50 \mathrm{mM}$ Tris-acetate, $\mathrm{pH} 7.4$ ) for $30 \mathrm{~min}$ at RT. Then, the sections for total binding were incubated with $\left[{ }^{3} \mathrm{H}\right]$ kainate $(40 \mathrm{nM})$ while those for nonspecific binding were incubated in the presence of $\left[{ }^{3} \mathrm{H}\right]$ kainate $(40 \mathrm{nM})$ and L-glutamic acid ( $1 \mathrm{mM})$ in assay buffer for $60 \mathrm{~min}$ at $4^{\circ} \mathrm{C}$ (Greenamyre and Young, 1989). Binding of $\left[{ }^{3} \mathrm{H}\right]$ aspartate was determined following a 20 min preincubation in assay buffer ( $50 \mathrm{mM}$ Tris-acetate with $300 \mathrm{mM} \mathrm{NaCl}, \mathrm{pH} 7.4$ ) at $4{ }^{\circ} \mathrm{C}$. Sections for the determination of total binding were then incubated with $40 \mathrm{nM}\left[{ }^{3} \mathrm{H}\right] \mathrm{D}$-aspartate, while those for the determination of nonspecific binding were incubated with $40 \mathrm{nM}\left[{ }^{3} \mathrm{H}\right]_{\mathrm{D}}$-aspartate in the presence of $200 \mu \mathrm{M} \mathrm{D}$ aspartate in the assay buffer at $4^{\circ} \mathrm{C}$ for $20 \mathrm{~min}$ (Noga et al, 1997).

Following their incubations with the respective radioligands, all sections were washed twice in ice-cold assay buffer and then dipped in distilled water, to remove salts, before being dried in a stream of cool air. Sections used for the determination of $\left[{ }^{3} \mathrm{H}\right] \mathrm{MK}-801,\left[{ }^{3} \mathrm{H}\right] \mathrm{AMPA},\left[{ }^{3} \mathrm{H}\right]$ kainate, and $\left[{ }^{3} \mathrm{H}\right] \mathrm{D}$-aspartate were all apposed to Hyperfilm- $-\left[{ }^{3} \mathrm{H}\right]^{\mathrm{TM}}$ with $\left[{ }^{3} \mathrm{H}\right]$ microscales ${ }^{\mathrm{TM}}$ until an image suitable for analysis was obtained (AMPA, 14 days; kainate, 30 days; MK-801, 5 weeks; D-aspartate, 4 months). The film was then developed in Kodak D19 developer and fixed in Hypam fixative. The images were analyzed from film using the MCID M1 image analysis system. The sections used for the determination of $\left[{ }^{3} \mathrm{H}\right]$ CGP39653 were partially fixed overnight in paraformaldehyde fumes at RT, to prevent contamination of the unshielded tritium-sensitive phosphoimage plates, before being apposed to BAS-TR2025 phosphoimage plates with $\left[{ }^{3} \mathrm{H}\right]$ microscales ${ }^{\mathrm{TM}}$ until an image suitable for analysis was obtained (14 days). The phosphoimage plates were then scanned using a BAS5000 high-resolution phosphoimager and the images analyzed using AIS image analysis software.

For all autoradiographs, the density of the images was converted to $\mathrm{dpm} / \mathrm{mg}$ estimated tissue equivalent (ETE) by comparison with the standard curve generated using the relative densities of differing levels of radioactivity present on discrete zones of the $\left[{ }^{3} \mathrm{H}\right]$ microscales ${ }^{\mathrm{TM}}$. Using the specific activities of the appropriate radioligand, the values were converted to fmol/mg ETE.

As discussed previously (Scarr et al, 2003), all binding studies were of the single-point saturation design, where all available receptor sites are occupied by radioligand because the binding of each radioligand was measured at a concentration at least three times that of the $K_{\mathrm{D}}$ of the ligand for the receptor of interest (Hoffman et al, 1997; Nishikawa et al, 1983; Piggott et al, 1992; Sills et al, 1991).
Hence, specific binding (SB) of each radioligand, calculated as total binding ( $\mathrm{TB}$, three sections) minus the binding of the radioligand in the presence of a nonradioactive drug that competes for the same binding site (nonspecific, NSB, two sections), that is, $\mathrm{SB}=\mathrm{TB}-\mathrm{NSB}$, is a good estimate of the density of binding sites in the tissue studied (Rodbard, 1981).

\section{In Situ Hybridization}

A total of 10 sections $(14 \mu \mathrm{m})$ were cut from the same BA 9 blocks used for the in situ radioligand binding studies and thaw mounted on Superfrost slides.

Transcripts were detected using subclones as previously described (Healy and Meador-Woodruff, 1997; Ibrahim et al, 2000b; Ibrahim et al, 2000a; Meador-Woodruff et al, 1996, 2001b). Briefly, riboprobes were synthesized from linearized plasmids containing subclones corresponding to regions common to all splice and edited variants of each kainate receptor subunit transcript (summarized in Table 2). All subclones were prepared in either pBluescript SK $(-)$ or pBluescript $\mathrm{KS}(-)$, ranged from 469 to 865 bases, had similar G/C ratios $(<50 \%)$, encoded specific fragments of each sequence (Table 2), and were confirmed by nucleotide sequencing.

Riboprobes were synthesized using $100 \mu \mathrm{Ci}$ of dried $\left[{ }^{35} \mathrm{~S}\right]-$ UTP, $2.0 \mu \mathrm{l} 5 \times$ transcription buffer, $1 \mu \mathrm{l} 0.1 \mathrm{M}$ DTT, $1 \mu \mathrm{l}$ each of $10 \mathrm{mM}$ ATP, CTP, and GTP, $1 \mu \mathrm{g}$ of linearized plasmid DNA, $0.5 \mu$ RNA inhibitor, and $1.5 \mu \mathrm{l}$ of T3 or T7 RNA polymerase. After incubating for $2 \mathrm{~h}$ at $37^{\circ} \mathrm{C}, 1.0 \mu \mathrm{l}$ DNAse (RNAse-free) was added and incubated for $15 \mathrm{~min}$ at RT. The reaction mixture was then passed through Micro Bio-Spin P-30 Tris Chromatography Columns and the purified fractions eluted. DTT was added to each fraction at a final concentration of $0.01 \mathrm{M}$.

For each probe, two sections per subject were removed from $-80^{\circ} \mathrm{C}$ storage, fixed in $4 \%(\mathrm{w} / \mathrm{v})$ formaldehyde for $1 \mathrm{~h}$ at $\mathrm{RT}$, and rinsed three times in $2 \times$ SSC (standard saline citrate; $300 \mathrm{mM}$ sodium chloride and $30 \mathrm{mM}$ sodium citrate, $\mathrm{pH}$ 7.2). The sections were treated with $0.1 \mathrm{M}$ triethanolamine ( $\mathrm{pH}$ 8.0)/acetic anhydride, 400:1 (vol:vol), with stirring for $10 \mathrm{~min}$ at $\mathrm{RT}$, rinsed in $2 \times \mathrm{SSC}$ for $5 \mathrm{~min}$, and dehydrated through graded alcohols before being air dried. ${ }^{35}$ S-labelled probes were applied to the slides after diluting $3-5 \times 10^{6} \mathrm{cpm}$ in $400 \mu \mathrm{l}$ of hybridization buffer consisting of $50 \%$ deionized formamide, $3 \times$ SSC, $1 \times$ Denhardt's solution $(0.02 \%$ polyvinyl pyrrolidone, $0.02 \%$ Ficoll, and $0.02 \%$ bovine serum albumin), $2 \%$ yeast tRNA

Table 2 Characteristics of the Probes used for In Situ Hybridization Studies

\begin{tabular}{llcc} 
Probe & Accession number & Length (bp) & Region of gene in probe \\
\hline GluR5 & NM_0I724I & 765 & $177-942$ \\
GluR6 & ZII548 & 484 & $99-583$ \\
GluR7 & M83552 & 865 & $1-865$ \\
KAI & NM_0I2572 & 607 & $1-53 \mid$ \\
KA2 & NM_0I7262 & 469 & $1-469$ \\
\hline
\end{tabular}


$(10 \mathrm{mg} / \mathrm{ml}), 50 \mathrm{mM}$ sodium phosphate $(\mathrm{pH} 7.4)$, and $10 \%$ dextran sulfate in sterile water. Slides were covered with glass coverslips and placed in humid chambers saturated with $50 \%$ formamide at $55^{\circ} \mathrm{C}$ overnight. After $16 \mathrm{~h}$ of hybridization, the cover slips were removed and the sections washed three times in $2 \times$ SSC at RT, immersed in RNAse A $(200 \mathrm{mg} / \mathrm{ml}$ in $10 \mathrm{mM}$ Tris and $0.5 \mathrm{M} \mathrm{NaCl}, \mathrm{pH}$ 8.0 ) for $30 \mathrm{~min}$ at $37^{\circ} \mathrm{C}$, and then washed through decreasing concentrations of SSC to a final wash of $0.1 \times$ SSC at $60^{\circ} \mathrm{C}$ for $2 \mathrm{~h}$. Finally, the sections were dehydrated in graded ethanol solutions, allowed to air dry, placed in X-ray cassettes with $\left[{ }^{14} \mathrm{C}\right]$ microscale standards, and exposed to Kodak BIOMAX MR film (Kodak, Rochester, NY) for 7-14 days. For each probe, all subjects were run in the same experiment to eliminate interassay variability (Ibrahim et al, 2000b; Meador-Woodruff et al, 2001a,b).

Images were acquired by digitizing film images using a CCD camera with NIH Image software (version 1.61). Grayscale values were obtained for isodense bands identified for each probe, corrected for tissue background, and then converted to optical density (OD). OD values were then converted to amount of radioactivity bound (in $\mathrm{nCi} / \mathrm{g}$ ), determined from calibrated $\left[{ }^{14} \mathrm{C}\right]$ microscale standards (Amersham Biosciences, Piscataway, NJ) (Akbarian et al, 1996; Downs and Williams, 1984; Williams, 1982), which had been exposed alongside the slides for each probe. Using the number of uridine residues contained in each subclone and specific activity of $\left[{ }^{35} \mathrm{~S}\right] \mathrm{UTP}$, bound radioactivity was converted to concentration of mRNA per isodense band, expressed as femtomoles of mRNA per gram of tissue (fmol/g) (Clinton et al, 2003; McCullumsmith et al, 2003).

\section{Statistical Analysis}

For both in situ radioligand binding and in situ hybridization data, the Kolmogorov-Smirnov test was used to determine whether the data were normally distributed. Comparisons of both radiolabelled binding densities and mRNA levels across diagnostic groups and layers of binding were carried out with a two-way ANOVA. Where there were differences between the diagnostic groups, two-tailed unpaired $t$-tests were used to identify differences within each layer of binding. Binding densities for $\left[{ }^{3} \mathrm{H}\right] \mathrm{CGP} 39653$ and $\left[{ }^{3} \mathrm{H}\right] \mathrm{D}$-aspartate were homogenously distributed across all cortical layers; therefore, the data for these ligands were analyzed using two-tailed unpaired $t$-tests. Relationships between experimental parameters and potential confounding factors (PMI, age, $\mathrm{pH}$, psychotropic drug equivalents, and DOI) were analyzed using Pearson's single product moment correlations calculated using an assumed straight line fit. All analyses were carried out using GraphPad Prism Version 4.0 for Windows (GraphPad Software Inc., San Diego, California, USA).

\section{RESULTS}

\section{Demographics}

There were no significant differences in age or PMI between the diagnostic cohorts. Brain pH was significantly lower in the schizophrenic group compared to that of the controls $(6.17 \pm 0.06$ vs $6.34 \pm 0.04, p=0.025)$ (Table 1). However, there were no significant correlations between the demographic factors for either diagnostic group and measurements of either radioligand binding density or subunit mRNA levels $\left(r^{2}\right.$ values range from 0.494 to 0.0004 for the control group and from 0.438 to 0.0027 for the schizophrenic group).

\section{In Situ Radioligand Binding}

As the bindings of $\left[{ }^{3} \mathrm{H}\right] \mathrm{CGP} 39653$ and $\left[{ }^{3} \mathrm{H}\right] \mathrm{D}$-aspartate were homogenously distributed across all cortical laminae (Figure 1a and $\mathrm{b}$, respectively, insets show nonspecific binding), a single measure of radioligand binding was taken across the cortex. By contrast, $\left[{ }^{3} \mathrm{H}\right] \mathrm{MK}-801$ and $\left[{ }^{3} \mathrm{H}\right] \mathrm{AMPA}$ bindings were distributed in two distinct bands (Figure 1c and d, respectively, insets show nonspecific binding), which corresponded to cortical laminae I-III and IV-VI (MK-801) and cortical laminae I-II and III-VI (AMPA), respectively. $\left[{ }^{3} \mathrm{H}\right]$ Kainate binding was different in that it was distributed in three distinct bands (Figure 1e, inset shows nonspecific binding); these corresponded to cortical laminae I-II, III-IV, and V-VI.

\section{NMDA Receptors}

There was no significant variance in levels of $\left[{ }^{3} \mathrm{H}\right] \mathrm{MK}-801$ binding with diagnosis $(\mathrm{F}=0.44$, d.f. $=1,76, p=0.507$; Table 3), but there was significant variance in radioligand binding between layers $(\mathrm{F}=13.24$, d.f. $=1,76, p<0.001)$ with no significant interaction between these variables $(\mathrm{F}=0.18$, d.f. $=1,76, p=0.675)$. Two-tailed unpaired $t$-tests showed that the variation in $\left[{ }^{3} \mathrm{H}\right] \mathrm{MK} 801$ binding was due to a lower level of binding in cortical laminae IV-VI compared to that in laminae I-III in control subjects $(t=3.362$, d.f. $=38, p<0.005)$, with a strong trend to such a difference in the schizophrenic subjects $(t=2.018$, d.f. $=38, p=0.051)$.

Analysis of $\left[{ }^{3} \mathrm{H}\right] \mathrm{CGP} 39653$ binding with two-tailed Student's unpaired $t$-test revealed no significant difference between tissue from subjects with schizophrenia and controls $(t=0.08$, d.f. $=37, p>0.05$; Table 3$)$.

\section{AMPA Receptors}

There was significant variance in $\left[{ }^{3} \mathrm{H}\right]$ AMPA binding between layers $(\mathrm{F}=18.01$, d.f. $=1,74, p<0.001)$ but not between diagnosis $(\mathrm{F}=1.70$, d.f. $=1,74, p=0.196$; Table 3$)$, and there was no interaction between diagnosis and layer $(\mathrm{F}=0.14$, d.f. $=1,74, p=0.713)$. Further analysis between layers within diagnosis showed that the variation in radioligand binding was because of lower binding in laminae III-VI than in laminae I-II in both control $(t=3.746$, d.f. $=36, p<0.001)$ and schizophrenic $(t=2.742$, d.f. $=38, p<0.01)$ subjects.

\section{Kainate Receptors}

There was significant variance in $\left[{ }^{3} \mathrm{H}\right]$ kainate binding with diagnosis $(\mathrm{F}=20.03$, d.f. $=1,114, p<0.001$; Figure 1f $)$ and cortical layer $(\mathrm{F}=37.92$, d.f. $=2,74, p<0.001)$, but there was no interaction between diagnosis and layers $(\mathrm{F}=0.48$, d.f. $=2,114, p=0.62$ ). Further analysis between diagnoses with two-tailed Student's unpaired $t$-test revealed significant 


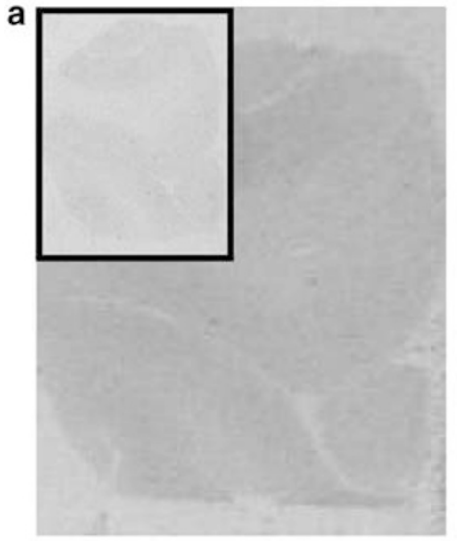

b

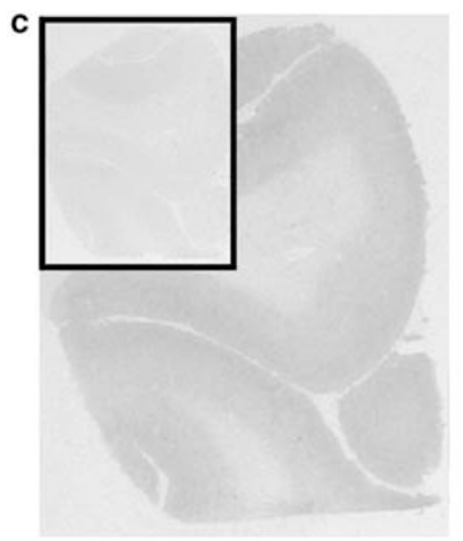

d
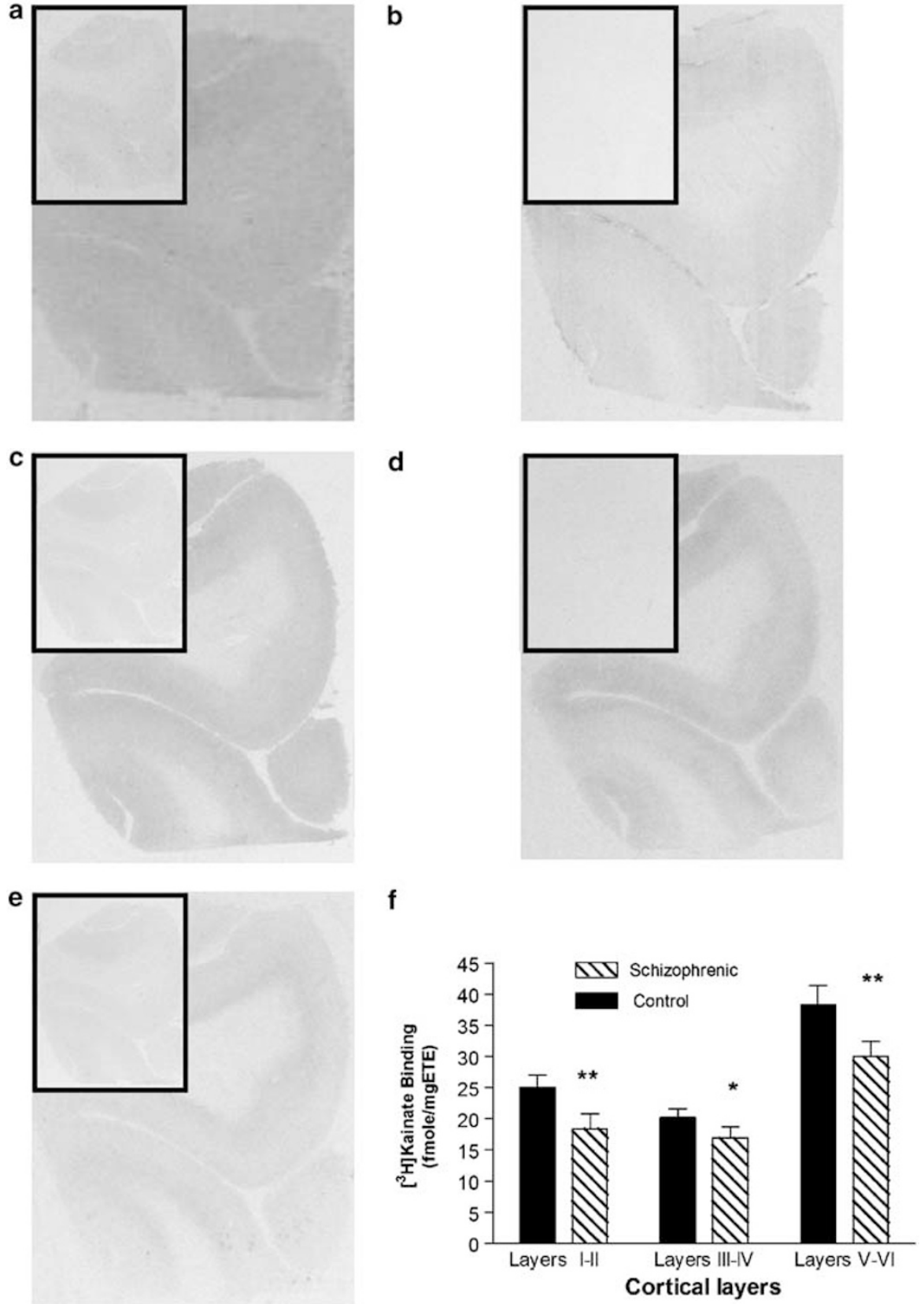

Figure I Autoradiographs of BA 9 showing the distribution of (a) $\left[{ }^{3} \mathrm{H}\right] \mathrm{CGP} 39653$, (b) $\left[{ }^{3} \mathrm{H}\right]$ aspartate, (c) $\left[{ }^{3} \mathrm{H}\right] \mathrm{MK}-80 \mathrm{I}$, (d) $\left[{ }^{3} \mathrm{H}\right] \mathrm{AMPA}$, and (e) $\left[{ }^{3} \mathrm{H}\right] \mathrm{kainate}$ binding (insets show nonspecific binding). In addition, $(f)$ is the graphical representation of $\left[{ }^{3} \mathrm{H}\right]$ kainate binding (mean \pm SEM) in fmol/mg ETE in BA 9 . ** $p \leqslant 0.01$. The closed columns represent data from control subjects while the hatched columns represent data from schizophrenic subjects.

decreases between all layers of $\left[{ }^{3} \mathrm{H}\right]$ kainate binding in tissue from subjects with schizophrenia compared to that from control subjects (layers I-II: $t=2.711$, d.f. $=38, p=0.01$; layers III-IV: $t=2.28$, d.f. $=38, p<0.05$; layers V-VI: $t=2.79$, d.f. $=38, p<0.01)$. Analysis within diagnosis showed that $\left[{ }^{3} \mathrm{H}\right]$ kainate binding in laminae I-II and IIIIV was lower than in laminae V-VI for both diagnostic cohorts (controls: $\mathrm{F}=21.35$, d.f. $=2,57, p<0.0001$; laminae I-II $v s$ laminae V-VI $p<0.001$; laminae III-IV $v s$ laminae V-VI $p<0.001 ; \quad$ Schizophrenics: $\mathrm{F}=16.59, \quad$ d.f. $=2,57$, $p<0.0001$; laminae I-II $v s$ laminae V-VI $p<0.001$; laminae III-IV $v s$ laminae V-VI $p<0.001$ ).

\section{High-Affinity Glutamate Uptake Sites}

Analysis of $\left[{ }^{3} \mathrm{H}\right]$ aspartate binding with two-tailed Student's unpaired $t$-test revealed no significant difference between tissue from subjects with schizophrenia and that from controls $(t=0.75$, d.f. $=38, p>0.05$; Table 3$)$.

\section{In Situ Hybridization}

The distribution for the low- (GluR5-7) and high-affinity kainate subunit (KA1 and 2) mRNA was visualized as five distinct isodense bands (Figure 2a-c) and four distinct 
Table 3 Summary of Radioligand Binding Data ( $\mathrm{fmol} / \mathrm{mg}$ ETE; mean \pm SEM) that was not Significantly Different between Diagnostic Cohorts

\begin{tabular}{|c|c|c|}
\hline Radioligand & Control & Schizophrenic \\
\hline \multicolumn{3}{|l|}{$\left[{ }^{3} \mathrm{H}\right] \mathrm{MK}-80 \mathrm{I}$} \\
\hline Layers I-III & $99.56 \pm 6.61$ & $92.08 \pm 8.65$ \\
\hline Layers IV-VI & $71.57 \pm 5.07$ & $69.88 \pm 6.79$ \\
\hline \multicolumn{3}{|l|}{$\left[{ }^{3} \mathrm{H}\right]$ CGP39653 } \\
\hline Layers I-VI & $32.70 \pm 2.51$ & $33.05 \pm 3.11$ \\
\hline \multicolumn{3}{|l|}{$\left[{ }^{3} H\right] A M P A$} \\
\hline Layers I-II & $249.40 \pm 11.01$ & $272.90 \pm 18.72$ \\
\hline Layers III-VI & $195.10 \pm 9.43$ & $208.20 \pm 14.34$ \\
\hline \multicolumn{3}{|l|}{$\left[{ }^{3} \mathrm{H}\right]$ aspartate } \\
\hline Layers I-VI & $35.95 \pm 3.06$ & $32.79 \pm 2.87$ \\
\hline
\end{tabular}
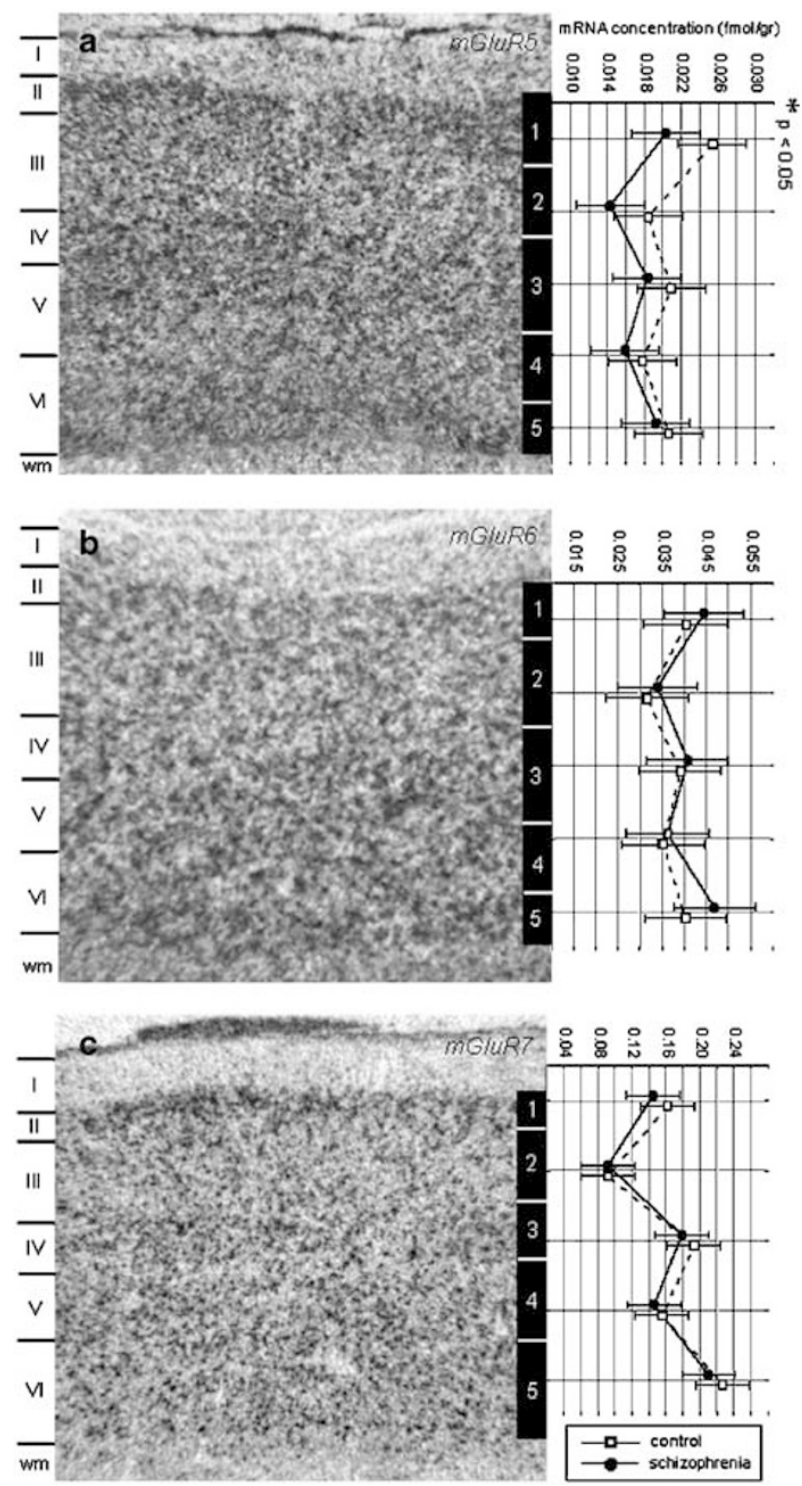

isodense bands (Figure $2 \mathrm{~d}$ and e), respectively. Comparison of the isodense bands with cortical laminae showed that the laminar distribution of mRNA was specific for each subunit. Isodense bands for GluR5 mRNA (Figure 2a) overlay cortical lamina II and the first third of lamina III (band 1), the remainder of lamina III (band 2), cortical lamina IV and the upper half of lamina V (band 3), the lower half of lamina $\mathrm{V}$ and the top quarter of lamina VI (band 4), and the deeper aspect of cortical lamina VI (band 5). Isodense bands for GluR6 mRNA (Figure 2b) overlay cortical lamina II and the top eighth of cortical lamina III (band 1), the remainder of cortical lamina III (band 2), lamina IV and the upper half of lamina V (band 3), the bottom half of lamina $\mathrm{V}$ and the upper half of lamina VI (band 4), and the lower half of lamina VI (band 5). For GluR7 mRNA (Figure 2c), isodense bands overlay cortical lamina II (band 1), III (band 2), IV (band 3), V (band 4),
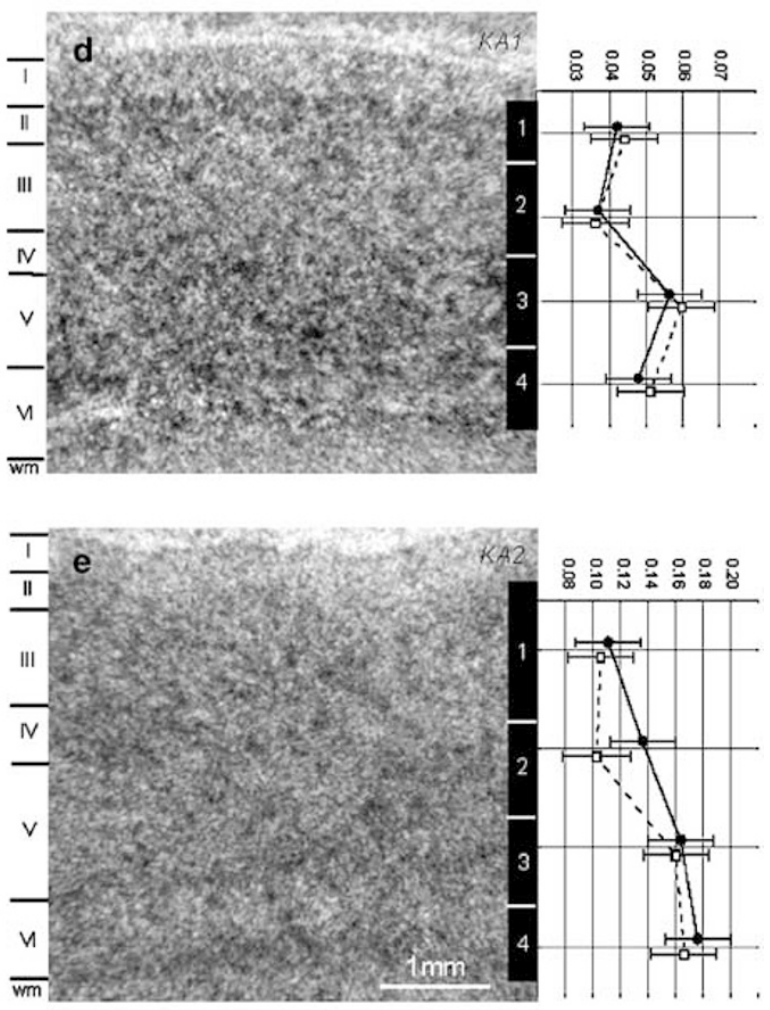

Figure 2 Images showing the distribution of mRNA for: (a) GluR5, (b) GluR6, (c) GluR7, (d) KAI, and (e) KA2 kainate receptor subunits across the dorsolateral prefrontal cortex. The cortical layers of each section are marked in their left margin. In their right margin, the graphs represent mRNA concentration in each of the isodense bands (black bar) in control (open squares) and schizophrenic (closed circles) subjects (mean $\pm 95 \%$ confidence limits) in femtomoles of mRNA per gram of tissue. 
and VI (band 5). For the high-affinity subunits, the mRNA for KA1 isodense bands overlay cortical lamina II (band 1), III (band 2), IV and V (band 3), and VI (band 4). For KA2 mRNA, isodense bands overlay cortical laminae II and III (band 1) as well as lamina IV (band 2), V (band 3), and VI (band 3).

\section{High-Affinity Kainate Subunits}

There was no significant variation in the levels of KA1 and KA2 subunit mRNA with diagnosis (KA1: $\mathrm{F}=0.36$, d.f. $=1,148, p=0.55$; KA2: $\mathrm{F}=1.93$, d.f. $=1,135, p=0.167$; Figure 2), but there was a variance between isodense bands for both subunits (KA1: $\mathrm{F}=8.14$, d.f. $=3,148, p<0.0001$; KA2: $\mathrm{F}=17.94$, d.f. $=3,135, p<0.0001$ ) without there being any interaction between these variables (KA1: $\mathrm{F}=0.09$, d.f. $=3,148, p=0.97$; KA2: $\mathrm{F}=0.38$, d.f. $=3,135, p=0.77$ ). Further analysis across isodense bands, within diagnoses, showed a significantly lower level of mRNA for KA1 in isodense band 2 compared to 3 (control: $\mathrm{F}=4.48$, d.f. $=3,72, p<0.001$, isodense band $2 v s$ isodense band 3 $p<0.01$; schizophrenic: $\mathrm{F}=3.65$, d.f. $=3,76, p<0.05$, isodense band $2 v s$ isodense band $3 p<0.05$ ). For KA2 subunit mRNA, there were lower levels of mRNA in isodense bands 1 and 2 compared to isodense bands 3 and 4 (control: $\mathrm{F}=8.42$, d.f. $=3,68, p<0.0001$, isodense band $1 v$ s isodense band $3 p<0.05$; isodense band $1 v s$ isodense band $4 p<0.01$; isodense band $2 v s$ isodense band $3 p<0.01$; isodense band $2 v s$ isodense band $4 p<0.01$; schizophrenic: $\mathrm{F}=10.49$, d.f. $=3,67, p<0.0001$, isodense band $1 v s$ isodense band 3 $p<0.001$; isodense band $1 v s$ isodense band $4 p<0.001$; isodense band $2 v s$ isodense band $3 p<0.05$; isodense band $2 v s$ isodense band $4 p<0.01$ ).

\section{Low-Affinity Kainate Subunits}

Levels of GluR5 subunit mRNA varied with diagnosis $(\mathrm{F}=6.42$, d.f. $=1,190, p<0.05$; Figure 2$)$ and isodense bands $(\mathrm{F}=4.00$, d.f. $=4,190, p<0.005)$ without there being any significant interaction between these variables $(\mathrm{F}=0.34$, d.f. $=4,190, p=0.85$ ). Further analysis between diagnoses with two-tailed Student's unpaired $t$-test failed to reveal significant differences in the levels of GluR5 subunit mRNA in any individual isodense band in subjects with schizophrenia compared to that in controls. Further analysis across isodense bands, within diagnoses, showed that in the control group, there was no variance associated with the different isodense bands $(\mathrm{F}=1.67$, d.f. $=4,95$, $p=0.16$ ). However, in the schizophrenic group, there was variance associated with the isodense bands $(\mathrm{F}=3.87$, d.f. $=4,95, p<0.01$ ); this was due to lower levels of GluR5 mRNA in isodense band 2 compared to isodense band 1 $(p<0.01)$.

Visual analysis of the data for GluR7 subunit mRNA suggested that some data points might be so variant that they would represent an outlier in comparison to the rest of the data set. This was confirmed with the Grubb's test, which showed that data from one control subject were outlier in four of the five isodense band measurements. There was no experimental reason to account for the increased variability in data from this subject and, therefore, to better assess the impact of the data on the population analysis, variance was analyzed with and without the outlying data points. Thus, using the full data set, there was variance in the levels of GluR7 subunit mRNA with both diagnosis $(\mathrm{F}=4.94$, d.f. $=1,190, p<0.05)$ and isodense bands $(\mathrm{F}=12.7$, d.f. $=4,190, p<0.0001)$ with no interaction between the two factors $(\mathrm{F}=0.10$, d.f. $=4,190$, $p=0.98$ ). Analysis of the proscribed data set showed no variance in the levels of GluR7 subunit mRNA with diagnosis $(\mathrm{F}=1.27$, d.f. $=1,185, p=0.26$; Figure 2$)$. There was variance associated with the isodense bands $(\mathrm{F}=17.46$, d.f. $=4,185, \quad p<0.0001)$, but there was no interaction between the two factors ( $\mathrm{F}=0.1$, d.f. $=4,185, p=0.98)$. The fact that data from a single subject could so profoundly affect statistical analyses added weight to the outcome from Grubb's analysis, which suggested that the data from one control subject were aberrant; therefore, further analysis was completed on a proscribed data set, which excluded the data from this particular subject.

Using the proscribed data, analysis between isodense bands, within diagnosis, showed that in both groups (control: $\mathrm{F}=8.18$, d.f. $=4,90, p<0.0001$; schizophrenic: $\mathrm{F}=9.49$, d.f. $=4,95, p<0.001)$ this variance was associated with lower levels of GluR7 mRNA in isodense band 2 compared to isodense bands 3 (control $p<0.01$; schizophrenic $p<0.001)$ and 5 ( $p<0.001$ for both groups), as well as lower levels in isodense band 4 compared to those in band 5 ( $p<0.05$ for both cohorts). In addition, in the control group, there is a higher level of GluR7 mRNA in isodense band 1 compared to isodense band $2(p<0.05)$, while in the schizophrenic cohort, there is a lower level of GuR7 mRNA in isodense band 1 than in isodense band 5 $(p<0.05)$.

There was no variance in levels of GluR6 subunit mRNA associated with diagnosis $(\mathrm{F}=1.53$, d.f. $=1,185, p=0.22$; Figure 2) or isodense bands $(\mathrm{F}=1.75$, d.f. $=4,185, p=0.14)$ and no interaction between the variables $(\mathrm{F}=0.18$, d.f. $=4,185, p=0.95)$.

\section{DISCUSSION}

This study has shown a decrease in the density of $\left[{ }^{3} \mathrm{H}\right]$ kainate binding in all cortical layers of BA 9 from subjects with schizophrenia. By contrast, there was no change in the levels of binding by the other four radioligands to other glutamatergic markers, including the NMDA and AMPA receptors, in tissue from the same cohorts of subjects. Under the conditions used in this study, $\left[{ }^{3} \mathrm{H}\right]$ kainate would bind to kainate receptors (Greenamyre and Young, 1989). Thus, our data are consistent with a decreased density of the kainate receptor in all cortical laminae from subjects with schizophrenia. In situ hybridization, using riboprobes directed against mRNAs for all of the kainate receptor subunits, showed a significant omnibus decrease in the levels of mRNA for the low-affinity kainate receptor subunit GluR5. Levels of mRNA for the other subunits were not different between diagnostic cohorts.

Previous studies have shown that changes in the glutamate receptors in the CNS from subjects with schizophrenia show regional specificity. This is demonstrated by studies that have investigated multiple cortical regions and shown an increase in the NMDA receptor in $\mathrm{BA}$ 
22 but not BA 10 (Nudmamud and Reynolds, 2001) from subjects with the disorder. Similarly, decreases in kainate receptors in the prefrontal but not the occipital cortex (Meador-Woodruff et al, 2001a) have been reported. Thus, to avoid introducing cortical regional variation in changes in glutamate receptors as a confounding variable in discussion of our study in BA 9, our findings will be compared to other studies in either this $\mathrm{CNS}$ region or in the dorsolateral prefrontal cortex (DLPFC; BA 9 and 46) from subjects with schizophrenia.

Our finding of decreased cortical kainate receptors in BA 9 partially replicates another study, which showed a decrease in kainate binding in the prefrontal cortex (BA 9, 11,32 , and 46) in schizophrenia (Meador-Woodruff et al, 2001a). However, this earlier study found decreases in KA2 mRNA and increased GluR7 mRNA in tissue from the same subjects, which contrasts with our finding of decreased GluR5 mRNA. Other studies have reported an increase (Nishikawa et al, 1983; Toru et al, 1988) or no change (Dean et al, 2001; Noga et al, 2001) in the levels of kainate receptors in the DLPFC from subjects with schizophrenia.

There are numerous possible explanations for the variation in results on the study of kainate, and other glutamatergic, receptors in the cortex from subjects with schizophrenia, for example, smaller cohorts (eg $n=8$ in the previous study from one of our laboratories), the use of different levels of diagnostic criteria (eg schizophrenia vs catatonic, disorganized, paranoid, residual, and undifferentiated forms of the disorder; American Psychiatric Association 2000), differences in the genetic homogeneity of the diagnostic cohorts (eg Nishikawa et al, 1983; Toru et al, 1988, mainly Japanese), and different tissue collection parameters (eg average age of subjects; Meador-Woodruff et al, 2001a). It is clearly difficult to ascertain the impact of these variables. The present study was carried out on a substantial, well-defined cohort of subjects, and the radioligand binding and measurement of mRNA for the kainate subunits were carried out separately, with researchers blind to the coding sequence used for the samples. Therefore, considering our data, it could be argued that decreases in the levels of kainate receptors are present in BA 9 from subjects with schizophrenia and that these decreases could be due to decreased expression of mRNA for the GluR5 subunit.

Our finding that $\left[{ }^{3} \mathrm{H}\right] \mathrm{AMPA}$ binding to the AMPA receptors is not changed in BA 9 from subjects with schizophrenia is in agreement with a number of previous studies in that region (Dean et al, 2001; Toru et al, 1988), the prefrontal cortex (BA 9, 11, 32, and 46) (Healy et al, 1998), and frontal cortex (region not specified) (Freed et al, 1993), although one study has reported an increase in the receptor in BA 46 with schizophrenia (Noga et al, 2001). Our study is novel in that cortical NMDA receptor density was measured using two radioligands, one of which binds within the ion channel $\left(\left[{ }^{3} \mathrm{H}\right] \mathrm{MK}-801\right)$ (Wong et al, 1986) of the receptor while the other binds to the glutamate binding site on the receptor $\left(\left[{ }^{3} \mathrm{H}\right] \mathrm{CGP} 39653\right)$ (Sills et al, 1991). The binding of neither radioligand was altered in schizophrenia, which is in agreement with a number of earlier studies (Dean et al, 1999, 2001; Kornhuber et al, 1989; Noga et al, 2001) (region not specified in the Kornhuber study). Hence, overall current data seem to suggest that changes in NMDA and AMPA receptors are not readily apparent in the DLPFC from subjects with schizophrenia.

Our finding of no change in $\left[{ }^{3} \mathrm{H}\right]$ aspartate binding in the DLPFC is in agreement with the only other study to be carried out in this area (BA 46) (Noga et al, 2001). These data would suggest that there is no change in the levels of high-affinity glutamate uptake sites in the DLPFC with schizophrenia.

Post-mortem studies in schizophrenia invariably have the confounding factor of the potential effects of pharmacotherapy prior to death. In this study, it was significant that there was no correlation between the levels of $\left[{ }^{3} \mathrm{H}\right]$ kainate binding or GluR5 mRNA and final recorded dose of antipsychotic drug. This suggests that there is no clear relationship between antipsychotic drugs received and changes in the kainate receptor in schizophrenia. In addition, another post-mortem study reported that mRNAs for NMDAR1, GluR1, GluR7, and KA1 subunits were lower in subjects with schizophrenia who were 'neuroleptic free' at death compared to those of controls and subjects treated with antipsychotics until death (Sokolov, 1998). These data infer that levels of mRNA for NMDAR1, GluR1, GluR7, and KA1 subunits can be increased because of antipsychotic drug treatment in humans. This hypothesis is partly supported by the report that clozapine, but not haloperidol, increases rat cortical mRNA for GluR7 (Healy and MeadorWoodruff, 1997), but this animal study suggests that changes in at least GluR7 mRNA may be drug class dependent. This is significant because in this study all schizophrenic subjects received typical antipsychotic drugs prior to death and it has been shown that treatment with such drugs either does not change (Spurney et al, 1999) or increases (Schmitt et al, 2003) levels of $\left[{ }^{3} \mathrm{H}\right]$ kainate binding in the rat cortex. Thus, together, these data would argue that our findings of decreased $\left[{ }^{3} \mathrm{H}\right]$ kainate binding and GluR5 subunit mRNA in tissue from subjects with schizophrenia are not simply a drug effect.

The impact of changes in kainate receptors on CNS function could be profound given that these receptors are both pre- (Vignes et al, 1998) and postsynaptic (Frerking et al, 1998), as well as being present on glial cells (Patneau et al, 1994). Furthermore, it is now accepted that the lowaffinity kainate subunits (GluR5-7) can form functional receptors that are both homomeric and heteromeric, but that the high-affinity subunits only form heteromeric receptors (Hollmann and Heinemann, 1994). Our data suggest that the change in $\left[{ }^{3} \mathrm{H}\right]$ kainate binding may be associated with a change in expression of the GluR5 subunit, which could cause changes in both homomeric and heteromeric forms of the receptor. Significantly, in the rat hippocampus, it has been shown that receptors incorporating the GluR5 subunit are involved in the regulation of glutamatergic transmission (Vignes et al, 1998), which results in a decrease in the ability of receptorspecific agonists to activate either AMPA or NMDA receptors, an effect that can be blocked by a GluR5preferring antagonist. In addition, it has also been shown that activating receptors incorporating the GluR5 subunit results in a reduction of $\gamma$-aminobutyric acid (GABA) inhibitory synaptic transmission (Clarke et al, 1997), an effect that is again reversed by the administration of a GluR5-preferring antagonist. Given that kainate can still 
block hippocampal GABAergic transmission in GluR5 knockout mice, it would appear that the GluR5 is not the only subunit involved in kainite-mediated GABA interactions (Mulle et al, 2000), suggesting that heteromeric rather than homomeric receptors are required for this process. Projecting these data to the human cortex, the decrease in kainate receptors in schizophrenia containing the GluR5 subunit would likely affect the 'fine-tuning' of both inhibitory and excitatory synaptic transmission in the CNS. Furthermore, the ability of kainate receptors to modulate the activity of AMPA and NMDA receptors, without necessarily affecting their densities, implies that profound changes in glutamatergic transmission could still occur, despite there being no changes in the levels of radioligand binding to either AMPA of NMDA receptors in this cohort.

Although this study found that only one component of the cortical glutamatergic system was changed in schizophrenia, the fact that the kainate receptor, and in particular the GluR5-containing kainate receptor, has been implicated in modulating the release of both glutamate and GABA suggests that changes in this receptor could have a pervasive impact on the functioning of the cortical system. Decreasing the inhibitory input of the GABAergic system and the excitatory effect of the glutamatergic system would potentially not only destabilize the balance of information entering and leaving the cortex, via the predominantly glutamatergic ascending and descending pathways, but also the processing of this information within the cortex by changing the relative influence of GABAergic interneurons and cortical glutamatergic neurons.

\section{ACKNOWLEDGEMENTS}

We thank Geoff Pavey for both technical assistance and as curator of the neural tissue repository, and Chris Hill, Ken Opeskin, David Copolov, and Nick Keks for their contribution to the tissue collection. Jaclyn McKenzie and Robyn Bradbury provided technical assistance. ES is a Ronald Phillip Griffith Research Fellow; this work was supported in part by a Stanley Research Centre Grant (03-RC-002).

\section{REFERENCES}

Akbarian S, Sucher NJ, Bradley D, Tafazzoli A, Trinh D, Hetrick WP et al (1996). Selective alterations in gene expression for NMDA receptor subunits in prefrontal cortex of schizophrenics. J Neurosci 16: 19-30.

American Psychiatric Association (1994). Diagnostic and Statistical Manual of Mental Disorders, 4th edn. American Psychiatric Association: Washington, DC. Vol 4.

American Psychiatric Association (2000). Diagnostic and Statistical Manual of Mental Disorders, 4th text revision. American Psychiatric Association: Washington, DC.

Breukel AI, Besselsen E, Lopes da Silva FH, Ghijsen WE (1998). A presynaptic $N$-methyl-D-aspartate autoreceptor in rat hippocampus modulating amino acid release from a cytoplasmic pool. Eur J Neurosci 10: 106-114.

Chumakov I, Blumenfeld M, Guerassimenko O, Cavarec L, Palicio $\mathrm{M}$, Abderrahim $\mathrm{H}$ et al (2002). Genetic and physiological data implicating the new human gene G72 and the gene for D-amino acid oxidase in schizophrenia. Proc Natl Acad.Sci USA 99: $13675-13680$.
Clarke VR, Ballyk BA, Hoo KH, Mandelzys A, Pellizzari A, Bath CP et al (1997). A hippocampal GluR5 kainate receptor regulating inhibitory synaptic transmission. Nature 389: 599-603.

Clinton SM, Haroutunian V, Davis KL, Meador-Woodruff JH (2003). Altered transcript expression of NMDA receptorassociated postsynaptic proteins in the thalamus of subjects with schizophrenia. Am J Psychiatry 160: 1100-1109.

Dean B, Hussain T, Hayes W, Scarr E, Kitsoulis S, Hill C et al (1999). Changes in serotonin2A and GABA(A) receptors in schizophrenia: studies on the human dorsolateral prefrontal cortex. J Neurochem 72: 1593-1599.

Dean B, Pavey G, McLeod M, Opeskin K, Keks N, Copolov D (2001). A change in the density of $\left[{ }^{3} \mathrm{H}\right]$ flumazenil but not $\left[{ }^{3} \mathrm{H}\right]$ muscimol binding, in Brodmann's Area 9 from subjects with bipolar disorder. J Affect Disord 66: 147-158.

Downs AM, Williams MA (1984). An improved approach to the analysis of autoradiographs containing isolated sources of simple shape: method, theoretical basis and reference data. J Microsc 136(Part 1): 1-22.

Fagg GE, Foster AC (1983). Amino acid neurotransmitters and their pathways in the mammalian central nervous system. Neuroscience 9: 701-719.

Freed WJ, Dillon-Carter O, Kleinman JE (1993). Properties of $\left[{ }^{3} \mathrm{H}\right]$ AMPA binding in postmortem human brain from psychotic subjects and controls: increases in caudate nucleus associated with suicide. Exp Neurol 121: 48-56.

Frerking M, Malenka RC, Nicoll RA (1998). Synaptic activation of kainate receptors on hippocampal interneurons. Nat Neurosci 1: 479-486.

Goff DC, Coyle JT (2001). The emerging role of glutamate in the pathophysiology and treatment of schizophrenia. Am J Psychiatry 158: 1367-1377.

Greenamyre JT, Young AB (1989). Synaptic localization of striatal NMDA, quisqualate and kainate receptors. Neurosci Lett 101: 133-137.

Harrison PJ, Weinberger DR (2005). Schizophrenia genes, gene expression, and neuropathology: on the matter of their convergence. Mol Psychiatry 10: 40-68.

Healy DJ, Haroutunian V, Powchik P, Davidson M, Davis KL, Watson SJ et al (1998). AMPA receptor binding and subunit mRNA expression in prefrontal cortex and striatum of elderly schizophrenics. Neuropsychopharmacology 19: 278-286.

Healy DJ, Meador-Woodruff JH (1997). Clozapine and haloperidol differentially affect AMPA and kainate receptor subunit mRNA levels in rat cortex and striatum. Brain Res Mol Brain Res. 47: 331-338.

Hill C, Keks N, Roberts S, Opeskin K, Dean B, Copolov D (1999). Diagnostic Instrument for Brain Studies. Mental Health Research Institute: Melbourne, Australia.

Hoffman KB, Kessler M, Lynch G (1997). Sialic acid residues indirectly modulate the binding properties of AMPA-type glutamate receptors. Brain Res 753: 309-314.

Hollmann M, Heinemann S (1994). Cloned glutamate receptors. Annu Rev Neurosci. 17: 31-108.

Ibrahim HM, Healy DJ, Hogg Jr AJ, Meador-Woodruff JH (2000a). Nucleus-specific expression of ionotropic glutamate receptor subunit mRNAs and binding sites in primate thalamus. Brain Res Mol Brain Res. 79: 1-17.

Ibrahim HM, Hogg AJ, Healy DJ, Haroutunian V, Davis KL, Meador-Woodruff JH (2000b). Ionotropic glutamate receptor binding and subunit mRNA expression in thalamic nuclei in schizophrenia. Am J Psychiatry 157: 1811-1823.

Jansen KL, Faull RL, Dragunow M, Waldvogel H (1990). Autoradiographic localisation of NMDA, quisqualate and kainic acid receptors in human spinal cord. Neurosci Lett 108: $53-57$.

Johnson M, Perry EK, Ince PG, Shaw PJ, Perry RH (1993). Autoradiographic comparison of the distribution of $\left[{ }^{3} \mathrm{H}\right] \mathrm{MK} 801$ 
and $\left[{ }^{3} \mathrm{H}\right] \mathrm{CNQX}$ in the human cerebellum during development and aging. Brain Res 615: 259-266.

Kingsbury AE, Foster OJ, Nisbet AP, Cairns N, Bray L, Eve DJ et al (1995). Tissue $\mathrm{pH}$ as an indicator of mRNA preservation in human post-mortem brain. Brain Res Mol Brain Res 28: 311-318. Kornhuber J, Mack-Burkhardt F, Riederer P, Hebenstreit GF, Reynolds GP, Andrews HB et al (1989). $\left.{ }^{3} \mathrm{H}\right] \mathrm{MK}-801$ binding sites in postmortem brain regions of schizophrenic patients. J Neural Transm 77: 231-236.

Lahti AC, Koffel B, LaPorte D, Tamminga CA (1995). Subanesthetic doses of ketamine stimulate psychosis in schizophrenia. Neuropsychopharmacology 13: 9-19.

Loo PA, Braunwalder AF, Williams M, Sills MA (1987). The novel anticonvulsant MK-801 interacts with central phencyclidine recognition sites in rat brain. Eur J Pharmacol 135: 261-263.

Luisada PV (1978). The phencyclidine psychosis: phenomenology and treatment. NIDA Res Monogr 241-253.

McCullumsmith RE, Stincic TL, Agrawal SM, Meador-Woodruff JH (2003). Differential effects of antipsychotics on haloperidolinduced vacuous chewing movements and subcortical gene expression in the rat. Eur J Pharmacol 477: 101-112.

Meador-Woodruff JH, Davis KL, Haroutunian V (2001a). Abnormal kainate receptor expression in prefrontal cortex in schizophrenia. Neuropsychopharmacology 24: 545-552.

Meador-Woodruff JH, Healy DJ (2000). Glutamate receptor expression in schizophrenic brain. Brain Res Brain Res Rev 31: 288-294.

Meador-Woodruff JH, Hogg Jr AJ, Smith RE (2001b). Striatal ionotropic glutamate receptor expression in schizophrenia, bipolar disorder, and major depressive disorder. Brain Res Bull 55: 631-640.

Meador-Woodruff JH, King RE, Damask SP, Bovenkerk KA (1996). Differential regulation of hippocampal AMPA and kainate receptor subunit expression by haloperidol and clozapine. $\mathrm{Mol}$ Psychiatry 1: 41-53.

Mulle C, Sailer A, Swanson GT, Brana C, O'Gorman S, Bettler B et al (2000). Subunit composition of kainate receptors in hippocampal interneurons. Neuron 28: 475-484.

Nakanishi S (1992). Molecular diversity of glutamate receptors and implications for brain function. Science 258: 597-603.

Nishikawa T, Takashima M, Toru M (1983). Increased $\left[{ }^{3} \mathrm{H}\right]$ kainic acid binding in the prefrontal cortex in schizophrenia. Neurosci Lett 40: 245-250.

Noga JT, Hyde TM, Bachus SE, Herman MM, Kleinman JE (2001). AMPA receptor binding in the dorsolateral prefrontal cortex of schizophrenics and controls. Schizophr Res 48: 361-363.

Noga JT, Hyde TM, Herman MM, Spurney CF, Bigelow LB, Weinberger DR et al (1997). Glutamate receptors in the postmortem striatum of schizophrenic, suicide, and control brains. Synapse 27: 168-176.

Nudmamud S, Reynolds GP (2001). Increased density of glutamate/ $N$-methyl-D-aspartate receptors in superior temporal cortex in schizophrenia. Neurosci Lett 304: 9-12.

Numakawa T, Yagasaki Y, Ishimoto T, Okada T, Suzuki T, Iwata N et al (2004). Evidence of novel neuronal functions of dysbindin, a susceptibility gene for schizophrenia. Hum Mol Genet 13: 2699-2708.

Owen MJ, O'Donovan MC, Harrison PJ (2005). Schizophrenia: a genetic disorder of the synapse? BMJ 330: 158-159.
Patneau DK, Wright PW, Winters C, Mayer ML, Gallo V (1994). Glial cells of the oligodendrocyte lineage express both kainateand AMPA-preferring subtypes of glutamate receptor. Neuron 12: $357-371$.

Perkinton MS, Sihra TS (1999). A high-affinity presynaptic kainate-type glutamate receptor facilitates glutamate exocytosis from cerebral cortex nerve terminals (synaptosomes). Neuroscience 90: 1281-1292.

Piggott MA, Perry EK, Perry RH, Court JA (1992). $\left.{ }^{3} \mathrm{H}\right] \mathrm{MK}-801$ binding to the NMDA receptor complex, and its modulation in human frontal cortex during development and aging. Brain Res 588: $277-286$.

Remington GJ (1999). Antipsychotics (neuroleptics). In: Bezchilbnyk-Butler KZ, Jeffries JJ (eds). Clinical Handbook of Psychotrophic Drugs, 9th edn. Hogrefe \& Huber: Seattle, Toronto, Gottingen, Bern. pp 55-84.

Rodbard D (1981). Mathematics and statistics of ligand assays. In: Langan J, Clapp JJ (eds). Ligand Assay: Analysis of International Developments on Isotopic and Nonisotopic Immunoassay, 1st edn. Masson: New York. pp 55-101.

Scarr E, Pavey G, Sundram S, MacKinnon A, Dean B (2003). Decreased hippocampal NMDA, but not kainate or AMPA receptors in bipolar disorder. Bipolar Disord 5: 257-264.

Schmitt A, May B, Muller B, Jatzko A, Petroianu G, Braus DF et al (2003). Effects of chronic haloperidol and clozapine treatment on AMPA and kainate receptor binding in rat brain. Pharmacopsychiatry 36: 292-296.

Sills MA, Fagg G, Pozza M, Angst C, Brundish DE, Hurt SD et al (1991). ${ }^{3} \mathrm{H}$ ]CGP 39653: a new $N$-methyl-D-aspartate antagonist radioligand with low nanomolar affinity in rat brain. Eur $J$ Pharmacol 192: 19-24.

Sokolov BP (1998). Expression of NMDAR1, GluR1, GluR7, and KA1 glutamate receptor mRNAs is decreased in frontal cortex of 'neuroleptic-free' schizophrenics: evidence on reversible upregulation by typical neuroleptics. J Neurochem 71: 2454-2464.

Spurney CF, Baca SM, Murray AM, Jaskiw GE, Kleinman JE, Hyde TM (1999). Differential effects of haloperidol and clozapine on ionotropic glutamate receptors in rats. Synapse 34: 266-276.

Stefansson H, Sigurdsson E, Steinthorsdottir V, Bjornsdottir S, Sigmundsson T, Ghosh S et al (2002). Neuregulin 1 and susceptibility to schizophrenia. Am J Hum Genet 71: 877-892.

Tamminga C (1999). Glutamatergic aspects of schizophrenia. $\mathrm{Br} J$ Psychiatry Suppl 37: 12-15.

Toru M, Watanabe S, Shibuya H, Nishikawa T, Noda K, Mitsushio $\mathrm{H}$ et al (1988). Neurotransmitters, receptors and neuropeptides in post-mortem brains of chronic schizophrenic patients. Acta Psychiatr Scand 78: 121-137.

Vignes M, Clarke VR, Parry MJ, Bleakman D, Lodge D, Ornstein PL et al (1998). The GluR5 subtype of kainate receptor regulates excitatory synaptic transmission in areas CA1 and CA3 of the rat hippocampus. Neuropharmacology 37: 1269-1277.

White PF, Way WL, Trevor AJ (1982). Ketamine-its pharmacology and therapeutic uses. Anesthesiology 56: 119-136.

Williams MA (1982). Autoradiography: its methodology at the present time. J Microsc 128(Part 1): 79-94.

Wong EH, Kemp JA, Priestley T, Knight AR, Woodruff GN, Iversen LL (1986). The anticonvulsant MK-801 is a potent N-methyl-D-aspartate antagonist. Proc Natl Acad Sci USA 83: 7104-7108. 